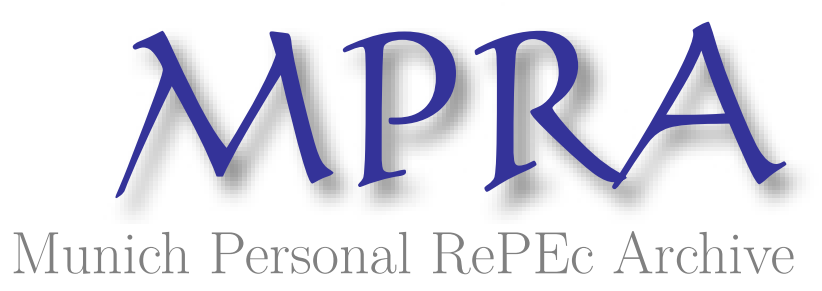

\title{
Application of Gravity Model to the Analysis of Cross-Country Differences in the Levels of Institutional Development
}

\author{
Dashkeev, Vladimir and Freinkman, Lev \\ University of Washington, Seattle, Academy of National Economy, \\ Moscow
}

27 February 2011

Online at https://mpra.ub.uni-muenchen.de/55427/

MPRA Paper No. 55427, posted 22 Apr 2014 04:33 UTC 


\title{
Application of Gravity Model to the Analysis of Cross-Country Differences in the Levels of Institutional Development
}

\author{
Vladimir Dashkeev (University of Washington, Seattle) and Lev Freinkman (Academy of National \\ Economy, Moscow) ${ }^{1}$
}

February 2011

\begin{abstract}
This paper presents an econometric model intended to explain fundamental cross-country differences in the quality of national economic institutions by using the set of economic, geographical, cultural and historical factors. Our key research hypothesis claims that bilateral trade may be working as a critical channel for institutional evolution, including through import of institutions by less developed countries from their more institutionally advanced trade partners. We follow logic of the modified gravity model of foreign trade to justify the model specification. Econometric analysis was conducted on the performance data of more than 100 countries in 1996-2006. Our results support the hypothesis that many factors that drive international institutional differences are identical to those that define intensity of trade interactions in the traditional gravity model. As a result, global institutional progress has been showing particular historic and geographical patterns. We come to the conclusion that, after controlling for differences in the levels of per capita income, institutional cross-country differences are significantly influenced by countries' location and geographic neighborhood, and with time countries tend to form homogeneous geographic clusters by the level of institutional development.
\end{abstract}

${ }^{1}$ E-mail: vvd@u.washington.edu, lfreinkman@gmail.com, respectively 


\section{Contents}

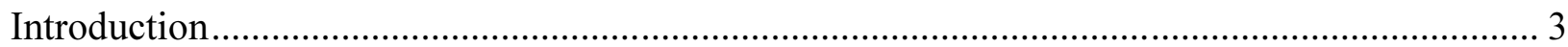

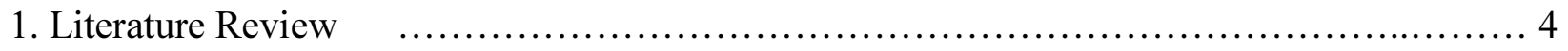

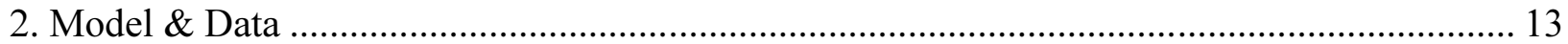

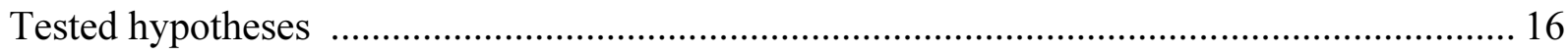

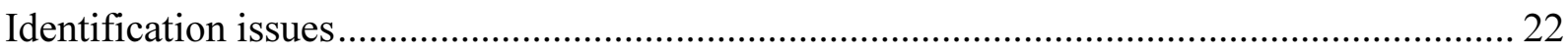

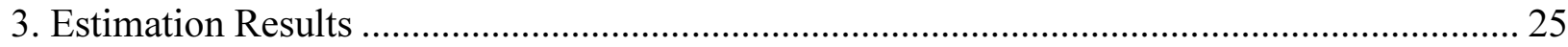

Basic Specification of the Modified Gravity Model ...................................................... 2626

Extended Specification of the Modified Gravity Model ....................................................... 29

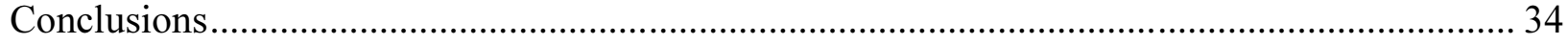

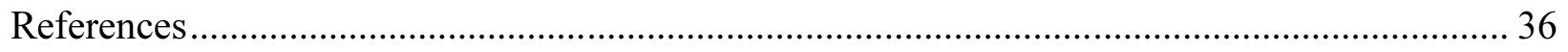




\section{Introduction}

A major theoretical and empirical contribution of institutional economics relates to its emphasis on the links between cross-country differences in income and variation in the quality of national institutions, which include such components as effectiveness of property rights protection, contract enforcement, transparency and independence of the judicial system, quality and accountability of governance, depth and stability of financial markets, etc. This in turns poses a question: what may explain differences in quality of institutions across countries?

This paper attempts to contribute to empirical analysis of institutional development and to explain international differences in quality of institutions using the framework of the gravity model of trade. Traditionally the gravity model is employed to explain international trade flows with geographic distances between trade partners, sizes of their economies and some other geographic, political and historic factors ${ }^{2}$. This paper uses logic of modified gravity model to suggest a new way to analyze and explain cross-country differences in institutional development. A key feature of our model relates to the introduction of a particular dependent variable -institutional distance between two countries (used as an explanatory variable in the model instead of trade flows between them). ${ }^{3}$

Our modeling approach is based on the following central hypothesis: institutional differences between two countries are negatively correlated with the intensity of their bilateral trade. To support higher volumes of mutual trade countries need to make adjustments in their economic institutions and ensure some degree of their compatibility. Trade-related needs are an important driver of institutional innovation, which often takes place the form of institutional imports (borrowing new institutions from a more institutionally developed trade partner). In this framework, various traditional drivers of intensity of bilateral trade commonly employed by various modifications of the gravity model (such as geographic distances, existence of common

\footnotetext{
${ }^{2}$ For example, Tinbergen (1962)

${ }^{3}$ Non-trade applications of gravity model are rather common. Some examples of such applications include Frankel and Rose (2005), Hahm and Shin (2009) and are reviewed below.
} 
border, membership in the same economic bloc, etc.) would also be the factors that shape core institutional differences between the countries.

The outline of the paper is as follows. Section 1 briefly surveys literature on the inter-links between institutions, geography, trade, and economic growth. Section 2 presents our modified gravity model and discusses specifications and hypotheses that are tested in this paper. The results of econometric estimation are presented in section 3. The last section concludes by suggesting possible interpretation of our results.

\section{Literature Review}

\section{Institutions and Growth}

The contemporary economic theory puts a heavy emphasis on importance of institutions for economic development. It is commonly admitted that stability and effectiveness of institutions are the basic condition for the flow of investments and development of entrepreneurship. One of the authoritative papers in this field, "Institutions Rule", by Dani Rodrik, Arvind Subramanian, and Francesco Trebbi (2002) shows that in the multi-country regressions institutional quality (first of all, indicators for the quality of property rights and legal system) explains the difference in the long-run growth rates better than other fundamental factors. According to their results, improvement in institutional quality by one standard deviation corresponds to an increase in per capita income by a factor of 6.4, which is equivalent to the actual difference in GDP per capita between, e.g., Bolivia and South Korea.

While neoclassical and endogenous growth theory frameworks treat investment in physical capital, human capital, knowledge, and innovations as the primary determinants of the economic growth, institutional approach considers investments along with other factors as a consequence of formation and improvement in effectiveness of the institutional framework. For example, poor property rights enforcement results in lower investment to GDP ratio as compared to a similar economy with better enforcement. In the institutional environment with poorly protected property rights entrepreneurs opt for suboptimal, from the growth prospective, means and 
amounts of capital investment. ${ }^{4}$ Owners of factors of production are usually ready to make sufficient investments in the development of these factors if and only if they are sure that their property rights are secured properly.

Therefore, precise determination of property rights and their effective enforcement is one of the key determinants of successful economic development. Respectively, weak property protection and poor quality of the institutional environment are in general the main barriers to economic growth, especially in developing countries. ${ }^{5}$ Robert Barro (1996) in his prominent paper "Determinants of Economic Growth: A Cross-Country Empirical Study" uses such institutional indicators as quality of property rights protection and rule of law as the main determinants of development. Philip Keefer and Stephen Knack (1995) showed that weak property rights protection affects economic growth negatively. Mancur Olson and his colleagues ${ }^{6}$ emphasized the role of modernization of formal and informal institutions in the post-World War II Germany and Japan for growth acceleration in those countries. The new economic structures created there according to the principles of free and competitive markets replaced monopolistic structures that were dominating before the WWII. This change promoted fast recovery and further development of German and Japanese economies.

It is worth emphasizing that institutional factors are significant in the models that look for explanation of the long run growth and international differences in the levels of per capita income. Attempts to explain short-run differences in growth rates with institutional variables have produced the results that are statistically less significant and less robust. ${ }^{7}$ However, such results are consistent with research findings of the episodes of growth acceleration in different countries around the world. Often no fundamental improvement of local institutions is necessary to trigger such growth acceleration. Growth can start without such changes if it's possible to weaken effect of other, non-institutional barriers to development (Hausmann, Pritchett, and

\footnotetext{
${ }^{4}$ E.g., see illustration of this idea in the model by Lindner, Strulik (1999)

${ }^{5}$ E.g. Clague (1997)

${ }^{6}$ Analysis of new institutional approach and analysis of institutional changes in Germany and Japan are presented in Mancur Olson's chapter "The New Institutional Economics: The Collective Choice Approach to Economic Development" in Clague (1997) and in the paper by Keefer, Knack (1997).
}

${ }^{7}$ Hausmann, Pritchett, Rodrik (2005) 
Rodrik, 2005). Experiences of China and India are the illustration of successful growth that started before any serious institutional change took place. These countries launched large-scale institutional reforms only after their economies grew at a high rate for several years.

To the contrary, over the longer time period the role of institutional factors is critical. To sustain growth without improvement of institutions is difficult, often not possible, i.e. the initial acceleration of development fails to become stable, unless adequate institutions are in place. This is a fundamental weakness of growth patterns in authoritarian and non-market economies. The former are quite capable to generate impressive short-run growth rates by means of mobilization of their internal resources, but, as a rule, they are unable to maintain that growth over a relatively long time intervals.

Literature on the role of institutions in the economic growth makes a special emphasis on two groups of institutional factors. These are the quality of legal system and the level of financial system development. A 1997-1998 series of papers by Andrei Shleifer, Rafael La Porta, Florencio Lopez-de-Silanes, and Robert Vishny presented the results of empirical study of the relationship between the quality of national legal institutions and growth. The authors argued that the type of legal system (either Anglo-Saxon system of common law or French civil law system) promoted or, correspondingly, hindered protection of private property rights and, therefore, positively or negatively affected the rate of financial markets development, level of private investment, and economic dynamics. The authors showed that the adaptation of the French civil law system creates risks for excessive administrative regulation of the economy as well as particular legal risks - risks of the redundant judicial formalism, greater complication and prolongation of legal procedures - that increase costs of law enforcement ${ }^{8}$.

Results of Andrei Shleifer et al. (1997, 1998) were elaborated by Thorsten Beck, Asli DemirgucKunt, Ross Levine, and Vojislav Maksimovic (2001). Their contribution was the demonstration of the fact that the type of legal system impacts economic growth not directly but rather through

\footnotetext{
${ }^{8} \mathrm{~A}$ significant part in the realization of property rights protection is assigned to real independence of the judiciary. The model of Rafael La Porta, Florencio Lopez-de-Silanes, Cristian Pop-Eleches, Andrei Shleifer (2004) shows that the countries whose national judiciary has greater independence and where the property rights are protected to the fuller extent have the institutional environment that is more favorable for intensive economic growth.
} 
the operations of financial markets, namely a degree of their development or their "depth". Thus, the role of financial services is crucial for successful realization of investment projects and respectively stable economic growth. Countries with more developed financial markets, ceteris paribus, receive greater capital investment flows as compared to countries with weaker financial institutions. According to Jeffrey Wurgler (2000) this effect is more prominent in high-tech industries, which tend to benefit the most from the availability of credit resources and investment funding in the economy.

This strand of research was a sequel to the earlier studies by Robert King and Ross Levine (1993a, 1993b), who used the data on 80 countries to confirm close relationship between the depth of national financial systems, on one hand, and the long-run growth rates, rate of capital accumulation and improvement in effectiveness of capital stock utilization, on the other hand. Moreover, the attained level of development of the national financial sector - measured with such indicators as the ratio of banking sector assets to GDP or the private loans to GDP ratio correlates strongly with future growth rates.

\section{Endogeneity problem}

At present the economics mainstream does not question the existence of stable and statistically significant correlation between the quality of national institutions and the level of economic development. But with few exceptions (see p. 11), no analysis was undertaken yet on factors that may explain cross-country variation in the quality of institutions. Main discussions are centered instead on further elaboration of the causal relationship between institutions and growth. One of the central puzzles in the field is the endogeneity problem: whether institutions is the initial source of growth or, to the contrary, development of the institutions and their subsequent influence is itself the result of some other, deeper growth determinants.

The economic theory attributes growth determinants using terminology of Dani Rodrik (2003) ${ }^{9}$ either to the group of proximate or to the group of fundamental or deep factors. Conventional for the neoclassical models factors, such as labor, capital, and productivity comprise the group of

\footnotetext{
${ }^{9}$ The original framework of Rodrik does not incorporate all potential factors of growth, but his methodology is consistent with the contemporary view of the process of economic growth.
} 
proximate factors. To the group of fundamental factors Rodrik attributes quality of national institutions, international trade, ${ }^{10}$ and geographical characteristics of the country, such as availability of natural resources, climate, distance from the equator, accessibility to sea trade routes. Of all the above mentioned fundamental factors of growth only geography is apparently an exogenous factor, whereas institutions and international trade are shaped to a substantial degree by the national economic policy.

The above classification of growth factors is consistent with a number of critically important studies in the area of economic development, some of which are summarized below.

In 2001 Daron Acemoglu, Simon Johnson, James Robinson published the research results, in which legal institutions are claimed to be the fundamental factor of growth. The authors used data on malaria mortality that European setters confronted in the period of XVII - XIX centuries in the New World, i.e. in Africa, Asia, America, and Australia, as well as the data on density of aboriginal population. These two variables, malaria mortality and indigenous population density, were used as proxies for a long-run trajectory of institutional development of these territories. Along with a set of control variables these two variables satisfactory explain large part of present-day cross-country differences in the quality of property rights protection. Acemoglu et al. interpreted this result as follows: European settlers migrated largely to the new territories with sparsely distributed native population and relatively moderate climate. Such characteristics of new lands led to replication of European institutional traditions and legal systems in those areas. Whereas in the territories with hostile for Europeans climate and high density of local population metropolis established a system of centralized colonial governance and used practice of extractive farming with heavy exploitation of native people. In these countries import of institutions from metropolis was quite limited.

Differences between these two types of colonization, Neo-Europes vs. extractive states, just deepened over the past centuries, including the period that started when the former colonies obtained independence. As Acemoglu et al. show, these early exploration and settlement differences have resulted in significant differences in the present quality of institutional

\footnotetext{
${ }^{10}$ Rodrik et al. refer to international trade as to "integration view" to emphasize the integrating role of the trade for market operations.
} 
environment, as measured by the effectiveness of property rights indicator. In their own turn, institutional differences were the decisive factor of divergence in long-run growth rates across the colonized territories and countries.

In spite of elegance of Acemoglu et al. arguments, Andrei Shleifer, Edward Glaeser, Rafael La Porta, and Florencio Lopez-de-Silanes (2004) questioned these results based on their own research, in which they argued that it is not the institutions that are the core driver of variation in economic growth, but the quality of human capital. Shleifer et al. noted that besides institutions settlers have imported to the colonies human capital, and furthermore, causality could go from human capital to legal institutions, and only then from institutions - to growth.

Quite opposite approach can be found in the paper by John Gallup, Jeffrey Sachs, and Andrew Mellinger (1999), who used only geographical factors to validate their hypothesis that geography crucially impacted both institutional development and growth. The authors improved upon the theoretical framework of such scholars as Fernand Braudel (1972, 1981-1984) and Jared Diamond (1997) and based on the results of their own empirical study came to a conclusion that geography is a fundamental factor of economic growth that determines subsequent developments of both human capital and the quality of institutions. Authors justified primacy of geography by the strict exogeneity of geographical factors, i.e. independence of national geographic characteristics from the pursued policy. In their work Gallup et al. analyzed such main geographic variables as location in the North of South hemisphere, distance from the sea trade routes, and type of climatic patterns. According to their results, the most advantageous for the long-run growth combination of geographical factors includes location in the North hemisphere, access to the sea trade routes, and moderate climate. Notice that favorable geographic characteristics positively relate to growth, on one hand, directly through lower transport costs and better health of population, greater crop productivity and higher birth rate of livestock, presence of natural resources and low cost of their extraction, and, on the other, indirectly through the age of settlements and density of population, both of which encourage growth through the agglomeration effect. 
William Easterly and Ross Levine (2003) and Dani Rodrick, Arvind Subramanian, and Francesco Trebbi (2002) almost simultaneously conducted a research and presented the models that included three fundamental factors of growth (institutions, trade, and geography).

Easterly and Levine did not find statistically significant support for the effect of key economic policy variables, including macroeconomic policy, participation in the international trade, and limits on capital movement, on growth. However, institutional variables influenced growth significantly and positively in that study.

The institutional development index played a key role for Easterley \& Levine's analysis. This index was based on 6 institutional characteristics originally suggested in a series of papers by Daniel Kaufmann, Aart Kraay, Pablo Zoido-Lobatón (1999a, 1999b), which developed into a family of World Bank World Development Indicators (WB WGI). Those characteristics summarize international differences in the quality of institutions for a large sample of countries according to the following dimensions:

1. Voice and accountability - measure of civil rights (freedom of expression, freedom of association), freedom of media, and accountability of government authorities;

2. Political stability and absence of violence - probability of change of the national government by non-constitutional mechanisms;

3. Government effectiveness - measure of quality of civic service and public sector services, competence of governmental officials, and credibility of government's commitment to announced policies;

4. Regulatory quality - measure of governmental involvement as well as quality of such involvement in operations of the commodity markets and banking system, degree of administrative control in the area of the new business start-ups, control of private sector operations and international trade;

5. Rule of law - degree of protection of individuals and their property from violence and theft, independence and effectiveness of judicial system, effectiveness of contract enforcement, and property rights;

6. Control of corruption - measure of abuse of governmental power to satisfy private interests. 
As noted above, Dani Rodrik et al. (2002) conducted a conceptually similar study and analyzed impact of institutions, geography, and international trade ${ }^{11}$. Similarly to Rodrik et al., Easterly and Levine made a conclusion that institutional variables have the best explanatory power for cross-country differences in the levels of economic development as compared to the other fundamental factors. However, these authors do not entirely reject influence of geography on economic growth, but argue that its influence is not direct, but rather stems indirectly through institutions.

Sensitivity of such econometric results to the specification changes and choice of institutional and geographical variables led to a paper by Jeffrey Sachs "Institutions Don't Rule" in 2003, in which he published the results that are different from those obtained by Easterly and Levine (2003) and Rodrik et al. (2002). His model included both institutional and geographic factors, but unlike his opponents, the estimates for geographic variables in his specification were significant. As a result, Sachs insisted on accuracy of his original conclusions that institutions could not completely explain international differences in growth and that part of the unexplained residual can be attributed to the geographic determinants.

\section{What may explain cross-country institutional differences?}

While profession seems to agree that institutions are critical for economic development, surprisingly little attention has been paid to statistical identification of factors that could explain cross-country variation in the quality of institutions. We managed to identify only a limited number of academic papers that focus on this research question. The common feature of these papers is that they tend to explain institutional variation in terms of differences in social characteristics of respective communities/nations and as such they focus on variables that for a mainstream economist sound as "almost anthropological".

For instance, Paulo Mauro (1995) pointed to importance of integrity of society for stability of institutions. This author based his analysis on the results of a model that used ethnolinguistic

\footnotetext{
${ }^{11}$ It is worth noting that as a measure of institutional quality Rodrick et al. used the rule of law index from the same WB WGI dataset by Kaufmann et al. that was utilized by Easterly and Levine.
} 
fractionalization indicator ${ }^{12}$ for explanation of corruption persistence in the society and government, i.e. degree of "underdevelopment" of national institutions. According to Mauro's research, countries with a highly developed sense of national identity, i.e. socially coherent states, ceteris paribus, have more developed and more stable national institutions, and, therefore, better prospects for economic growth.

William Easterly developed his earlier work and modified his approach to the analysis of institutions. In the 2006 paper William Easterly, Jozef Ritzan, and Michael Woolcock still consider institutions to be the crucial growth factor, but they do not treat them as a strictly exogenous factor. Instead, Easterly at al. treat social cohesion as the initial driver of growth, though again acting through the institutions. The authors argue that the state of society in terms of its cohesion at least partially determines strength of national institutions.

When members of the society do not trust each other, do not take an active civil position, and where income inequality is high, formation of effective institutions, i.e. stable generally accepted "rules of the game", is hindered. And vice versa, in a coherent society it is much easier to implement necessary reforms: citizens trust their government and, in particular, are ready to accept official arguments about withstanding short-run difficulties of reformation to be rewarded with the expected in the long-run benefits of the reforms. Common values of the society, which are related to the societal cultural and religious foundations and depth of linguistic differences, are another characteristic of social cohesion in Easterly et al. model.

The given above definition of social cohesion is close to the notion of social capital, introduced by Robert Putnam and John Helliwell (1995) for the study of social interaction at the micro level. In particular, Robert Putnam used this notion for analysis of the civil society in different regions of Italy and for the study of relationship between different social characteristics and economic growth. Proposed approach to the measurement of social capital takes into account the degree of citizen's participation in local community activities, participation in elections, membership in parties and various civic organizations. The authors claimed that there is a causal relationship

\footnotetext{
${ }^{12}$ The indicator is calculated as probability that 2 randomly selected citizens of one country belong to the same ethnolinguistic group and, consequently, have the common cultural norms and values.
} 
from social capital and degree of the civil society development to institutions and economic growth.

In our paper we intend to identify an alternative set of characteristics that could explain crosscountry variation in the quality of institutions. Our key hypothesis on the nature of institutional evolution and institutional conversion is centered on international trade dynamics. In short, we believe that factors driving growth in bilateral trade would also support bilateral institutional conversion. The following section provides some additional justification for this hypothesis. Here we just would like to make two upfront comments on peculiarities of our way of looking into factors of institutional development. First, its emphasis on trade allows for effective utilization of the methodology, in particular gravity model framework, developed in the last decades by mainstream economics for analysis of trade flows. Second, given strong interlinkages between trade, growth, and institutions, highlighted in the literature review above, our statistical analysis is designed to minimize potential distortions associated with endogeneity.

\section{Model \& Data}

\section{Gravity Model of Trade}

Known to physicists since Isaac Newton's works, the gravity model was originally applied to the study of international trade by Jan Tinbergen (1962). Since then, the model quickly gained in popularity and was used by many other economists. The functional form of the gravity model, used in economic research is presented in (1).

$\mathrm{F}_{i j}=\mathrm{G} \frac{\mathrm{M}_{i} \mathrm{M}_{j}}{\mathrm{Dist}_{i j}}$,

where $F_{i j}$ - international trade flows between countries $i$ and $j$, measured, e.g., as sum of their exports and imports,

$\mathrm{M}_{\mathrm{i}}, \mathrm{M}_{\mathrm{j}}$ - economic masses, e.g., GDP of, respectively, countries i \& j,

Dist $_{\mathrm{ij}}$ - geographic distances between countries i \& j, 


$$
\mathrm{G} \text { - gravitational constant. }
$$

Numerous studies have shown that the gravity model (GM), at large, fits volumes of international trade quite satisfactory. Since Tinbergen's work was published in 1962, multiple modifications of the model were introduced. Some of them added new explanatory variables, for example, common language, common border, membership in monetary, economic, and/or political unions. One of the most prominent examples of GM application at the end of the XX century is Jeffrey Frankel (1997). Other extensions modified the explained (LHS) variable to adapt the model to study other processes, such as international migration, FDI flows, environmental damage, or tourist flows.

Among the most remarkable GM modifications we would highlight the paper by Elhanan Helpman and Paul Krugman (1985), who modified the gravity model for monopolistic competition. Stephen Redding and Anthony Venables (2000) used the GM for developing the new economic geography framework. Joon-Ho Hahm and Kwanho Shin (2009) analyzed international financial integration, namely worldwide distribution of such financial assets as bank loans, long- and short-term debts, and portfolio equity holdings. Treating international allocation of financial assets as an explained variable, the authors used a traditional for gravity models set of explanatory variables, including GDP, and also included quality of institutional environment.

In this study we exploit the logic of gravity model not for the analysis of international trade flows, but rather for exploration of cross-country differences in the level of institutional development. We suppose that international differences in the quality of core economic institutions are directly related to intensity of trade interactions between these countries, and as such they are directly influenced by the traditional basic factors that determine the volumes of bilateral trade, such as the distance between these countries, presence of common border and common language. These factors appear to be exogenous not only with regard to the international trade characteristics but also with regard to the institutional quality.

Development of national institutions, according to our hypothesis, is significantly influenced by the institutional environment in the neighboring countries and in the countries that are the main trade partners. One of important paths for institutional evolution relates to import of institutions 
from geographical neighbors and trade partners. All factors that decrease transaction cost of trading between nations (common culture, geographic proximity, etc.) would support smoothing out institutional differences. Moreover, international trade plays a special and probably a key role in the process of institutional convergence: to stimulate bilateral trade both trade partners have to align their institutions. It seems reasonable to assume that, as the trade turnover grows, institutions of the more developed partner would be more often adopted (imported) by the less developed counterpart.

The logic of gravity model was used for this study because this model helps to identify main factors that define the intensity of trade between two countries. According to our research logic, the main factors used in the gravity model would promote convergence of institutions between countries that are engaged in bilateral trade. In other words, we do not use volumes of bilateral trade among our explanatory variables. Instead, we use factors which are seen as fundamental determinants of such trade flows according to the standard GM specification. Such an approach reduces potential endogeneity problems regularly observed in the analysis of interaction between trade and institutional development variables.

We have to admit that at this point we do not have a formal theoretical model to underpin our empirical analysis of cross-country institutional differences. Instead, we base our econometric investigation that follows on (i) our hypotheses that link cross-border institutional conversion with international trade, and (ii) an established tradition of applying the gravity model for studying various socio-economic processes. It is worth noting that initially the GM was estimated (see Tinbergen above) without rigorous theoretical underpinning. Only 17 years later the respective theory was developed (Anderson, 1979). And as seems such "theoretical shallowness" has been rather common in developing various modifications of GM.

For instance, the application of gravity model to analysis of international financial flows (e.g. Martin and Rey, 2004) so far has been driven primarily by empirical findings, not so much by theoretical considerations. As a rationalization of their model, Hahm and Shin (2009) claim that "the related literature indicates that the gravity model explains the pattern of bilateral asset holdings reasonably well". Use of the GM in this modification is justified explicitly by the common sense and by the observation that the volumes of bilateral trade in financial assets are positively correlated with the size of the economies and negatively correlated with transaction costs of trading, while transaction costs are correlated with the 
distances between the countries. Portes and Rey (2005) also argue that the transaction costs can be interpreted as information costs of trading, which are increasing with distance.

The above insight that information costs associated with international interactions could be modeled on the basis of the modified gravity model seems to be quite relevant to our analysis. The process of global dissemination of information about new institutions and their effectiveness is not without its costs. On average countries may find it is easier to acquire, process, and utilize information about new institutions if the source of such institutions is based either in the countries that are their geographical neighbors or in the countries with whom they have strong cultural links/similarities that make informational exchange less costly. This logic would suggest that, on the top of our core hypothesis that bilateral trade drives institutional conversion, there are additional reasons to believe that the same standard set of gravity model factors (distances, common border and language, etc. ${ }^{13}$ ) may be significantly correlated with crosscountry institutional differences.

\section{Tested Hypotheses}

We use our model to test the following hypotheses:

- Institutional distances between countries increase with differences between their levels of economic development (measured as difference in per capita GDP);

- Institutional differences increase in proportion with geographical remoteness of countries. That is, the greater geographical distance between any two countries, the greater, ceteris paribus, institutional gap between them;

- Common historical background and cultural heritage, measured by the presence of common border and language, even to a greater extent than geographical proximity, reduce the range of institutional variation;

- The structure of international trade flows at the country level (qualitative side of trade flows) also influences cross-country institutional variation. That is, similarities in both

\footnotetext{
${ }^{13}$ We would like to emphasize that most of these factors are exogenous with regard to trade and institutions.
} 
national trade structures (commodity composition) and degrees of trade openness ${ }^{14}$ diminish institutional differences between the countries.

- Institutional differences are to a significant degree associated with country clustering, on one hand, by economic criterions (e.g., OECD members), and, on the other hand, by geographic affiliation (main geographic regions),

- Finally, institutional differences are to a substantial extent related to historical heritage and geographical environment. This hypothesis implies that these differences are quite steady and highly inertial. Also regional trends or clustering plays a significant role in the institutional evolution: particular clusters of the countries located next to each other tend to show contemporaneous changes in the institutional quality. ${ }^{15}$

\section{Measuring institutional differences}

To measure the differences in the quality of national institutions, we introduce the concept of institutional distance between two countries. It is defined as a norm of two vectors in the ndimensional vector space of institutional quality. This space is formed by the World Bank family of indices World Governance Indicators. ${ }^{16} \mathrm{We}$ choose these indicators for construction of the institutional distance measure due to their broad coverage both in terms of the number of countries and the time span.

Family of the WGI indices is a product of the World Bank Institute. Their work was commenced at the end of 1990s by Daniel Kaufmann, Aart Kraay, and Massimo Mastruzzi with Pablo ZoidoLobatón. WGI indices are compiled from 1996 and until 2002 were published biannually and

\footnotetext{
${ }^{14}$ For the purposes of our analysis, trade openness seems to be an important complement to the set of standard GM factors because it helps to account for the economic scale. Openness reflects the degree of countries' exposure to world trade and therefore it measures the importance (relative to the size of domestic economy) of countries' interactions with trade partners (and with their national institutions).

${ }^{15}$ An example of such a cluster effect is given by a recent simultaneous acceleration of institutional changes in a large group of Central European countries due to their accession to the European Union.

${ }^{16}$ Daniel Kaufmann, Aart Kraay, and Massimo Mastruzzi (2007)
} 
since 2002 - annually. These indicators measure governance quality and are based on 33 data sources collected from 30 different organizations. ${ }^{17}$

Worldwide Governance indicators encompass main aspects of the governance in 212 countries of the world, which are reflected in the following six aggregated indicators: ${ }^{18}$

1. Voice and accountability

2. Political stability and absence of violence,

3. Government effectiveness,

4. Regulatory quality,

5. Rule of law,

6. Control of corruption

Data used to construct the indices are drawn from various surveys. Each survey results are used to create individual indicators that are then combined into 6 aggregated indices.

We have introduced here two types of the institutional distance measure.. They differ by the number of used WGI components, see equation (2) below. The first one is based on only four economic components (components 3 - 6: Government effectiveness; Regulatory quality; Rule of law; Control of corruption), while the second type includes all six indicators, including the political ones (adds Voice and accountability and Political stability and absence of violence).

$\|$ InstDist $_{i j, t} \|=\left[\sum_{n-1}^{N}\left(\text { Inst }_{i, n, t}-\text { Inst }_{j, n, t}\right)^{2}\right]^{1 / 2}$

where Inst Dist $\mathrm{ij}_{\mathrm{j}, \mathrm{t}}$ - institutional distance between countries $\mathrm{i} \& \mathrm{j}$ at year $\mathrm{t}$,

Inst $_{i, n, t}-$ value of WGI index $n$ for country $i, n=1, \ldots, 4$ (or 6 ) at year $t$.

For the purpose of this analysis, i.e. analysis of differences in the economic institutions, the 4component indicator appears to be advantageous. All its components are directly related to the quality of economic institutions. The 2 extra subindices, included in the 6-component indicator,

\footnotetext{
${ }^{17}$ Further information about the data sources used for the construction of the indicators and about the indicators are available on the website www.govindicators.org.

${ }^{18}$ See pp. 13-14 above for details.
} 
reflect predominantly the quality of political institutions, which, as frequently noted in the empirical growth studies literature, are to a smaller extent related to development of trade and basic economic inter-actions between the countries.

However, we prefer to keep the 6-component institutional distance measure in the analysis because it provides a broader scope of institutional characteristics and allows for the comparison of different types of institutional aspects: both economical and political. Therefore, it will be possible to attempt testing whether economic institutions behave similar to political one in this framework and check robustness of the model to variation in the design of explained variables.

International differences in institutional development are explained in this model with the following groups of variables:

A. Factors that influence the intensity of trade interactions between two countries, including geographic distances between them, differences in their basic geographic, cultural and historical characteristics, membership in the same economic group, location in the same geographic region, etc.;

B. Factors that describe the quality of bilateral trade the countries are engaged in indicators that track variation in national trade structures and in relative intensities of trade flows (trade openness);

C. Control variable: Bilateral differences in the level of economic development. ${ }^{19}$

\section{Model specification}

Depending on the model specification, it is estimated on 6697 or 7705 country-pairs over the period of 1996, 1998, 2000, 2002-2006.

We estimate the following 4 specifications (3-6):

\footnotetext{
${ }^{19}$ Which in their own turn are explained with physical capital accumulation and quality of human capital. Details are provided below.
} 
1. Basic model

$$
\begin{aligned}
\text { InstDist }_{i j, t} & =\beta_{0}+\beta_{1} * \text { Relative GDPc }_{i j, t}+\beta_{2} * \text { Dist }_{i j}+\beta_{3} * \text { Pop Dens }_{i j, t} \\
& +\beta_{4} * \text { Trade O pen } \\
i j, t & +\varepsilon_{i j, t}
\end{aligned}
$$

2. Basic model with export structure variable (Natural Resources Exports)

$$
\begin{aligned}
\text { InstDist }_{i j, t} & =\beta_{0}+\beta_{1} * \text { Relative GDPc }_{i j, t}+\beta_{2} * \text { Dist }_{i j}+\beta_{3} * \text { Pop Dens }_{i j, t} \\
& +\beta_{4} * \text { Trade Open }_{i j, t}+\beta_{5} * \text { Raw X } \\
i j, t & +\varepsilon_{i j, t}
\end{aligned}
$$

3. Extended model

$$
\begin{aligned}
\text { InstDist }_{i j, t} & =\beta_{0}+\beta_{1} * \text { Relative GDPc }_{i j, t}+\beta_{2} * \text { Dist }_{i j}+\beta_{3} * \text { Pop Dens }_{i j, t} \\
& +\beta_{4} * \text { Trade Open }_{i j, t}+\beta_{6} * \text { Latitude }_{i j}+\beta_{7} * \operatorname{Lang}_{i j}+\beta_{8} * \text { Land locked }_{i j} \\
& +\beta_{9} * \text { Same Country }_{i j}+\gamma * \text { Group Dum mies }_{i j}+\varepsilon_{i j, t}
\end{aligned}
$$

4. Extended model with export structure variable

$$
\begin{aligned}
\text { InstDist }_{i j, t} & =\beta_{0}+\beta_{1} * \text { Relative GDPc }_{i j, t}+\beta_{2} * \text { Dist }_{i j}+\beta_{3} * \text { Pop Dens }_{i j, t} \\
& +\beta_{4} * \text { Trade Open }_{i j, t}+\beta_{5} * \mathrm{RawX}_{i j, t}+\beta_{6} * \text { Latitude }_{i j}+\beta_{7} * \operatorname{Lang}_{i j} \\
& +\beta_{8} * \operatorname{Landlocked}_{i j}+\beta_{9} * \mathrm{Same} \mathrm{Country}_{i j}+\gamma * \text { Group Dummies }_{i j}+\varepsilon_{i j, t}
\end{aligned}
$$

where all variables besides dummies are in logarithms ${ }^{20}$ so that estimated coefficients can be interpreted as elasticities and

InstDist $\mathrm{ij}_{\mathrm{j}, \mathrm{t}}$ - Institutional distance between countries $\mathrm{i} \& \mathrm{j}$ at year $\mathrm{t}$, measured in 2 different ways using WB WGI data, as described above.

Relative GDPc $\mathrm{c}_{i j, t}$ - Ratio of GDP per capita in PPP (2005 prices) for country i \& j in year t. To ensure consistency of the data, in the nominator of the ratio there is the greater value

\footnotetext{
${ }^{20}$ Here and on by logarithms we refer to natural logarithms.
} 
of GDP per capita from the country-pair under consideration. The hat represents fitted values of the instrumented variable, see below for details ${ }^{21}$. Source: WB WDI 2009.

Dist $_{\mathrm{ij}}$ - Geographical distance between countries i \& j, measured as weighted distance between their main economic centers, i.e. the largest cities in each country. Share of population of these cities in the total nation's population is used as weights. ${ }^{22}$ Source of these and other geographical data: CEPII. ${ }^{23}$

Pop Dens $\mathrm{ij}_{\mathrm{j}, \mathrm{t}}$ - product of population density in countries i \& j at year t. Source: WB WDI 2009.

Trade Open ${ }_{\mathrm{ij}, \mathrm{t}}$ - absolute difference in trade openness between countries i \& j. In its turn, trade openness is defined as a ratio of sum of merchandise exports and imports to GDP. Source: WB WDI 2009.

Raw $\mathrm{X}_{\mathrm{ij}, \mathrm{t}}-\mathrm{absolute}$ difference in the shares of natural resources exports in merchandise exports for countries i \& j at year t. Natural resources exports include fuels, ores and metals. Source: WB WDI 2009;

Latitude $\mathrm{ij}_{\mathrm{ij}}$ - difference in absolute values of latitudes of countries i \& j. E.g., if we have two countries, one at latitude 40 North, and another - at 40 South, the value of this indicator is 0 . Source: CEPII;

\footnotetext{
${ }^{21}$ While our primary research objective is to explore the relationship between institutional differences and a number of historical and geographical factors, we are trying to control for several economic factors as well, including relative per capita income and differences in trade openness. And, while controlling for income differences, we take into account potential endogeneity problems in interaction between income and institutional variables as discussed below.

${ }^{22}$ Besides this variable we tried to use several alternative measures of geographical distances for our estimations: distances between national economic centers (the largest cities for all countries besides Canada, Russia, and the USA, for which two cites ( 3 for Russia) were chosen in the different regions), distances between the largest cities (1 city per country), and distances between the capital cities. The most significant results were obtained for the variable of weighted distances, next for the economic centers, then for the largest cities, and the least significant - for the capitals. These results appear to be logical. For large countries intensity of interaction with the rest of the world depends not on location of a single city, albeit the largest, but rather on location of several agglomerations, geographically dispersed.

${ }^{23}$ Center for Prospective Studies and International Information, http://www.cepii.fr/anglaisgraph/bdd/distances.htm Details can be found in Thierry Mayer, Soledad Zignago (2006).
} 
Lang $_{\mathrm{ij}}$ - dummy variable equals to 1 if at least $9 \%$ of population in both country i $\& \mathrm{j}$ speak the same language, equals to 0 otherwise. Source: CEPII;

Landlocked $\mathrm{ij}_{\mathrm{ij}}$ - dummy variable equals to 0 if none of the countries has direct access to sea routes, equals to 1 if only one of the countries in the given country pair has such access, and equals to 2 if both countries are landlocked. Source: CEPII;

Same Country $\mathrm{ij}_{\mathrm{ij}}$ - dummy variable equals to 1 if both country $\mathrm{i} \& \mathrm{j}$ used to be parts of the same state in the past. Source: CEPII;

Group Dummies $\mathrm{ij}_{\mathrm{ij}}$ - vector of dummy variables for main economic blocks / regions of the world according to the World Bank's classification: OECD, EE (East Europe), CIS (Commonwealth of Independent States), LAC (Latin America \& Caribbean), EA (East Asia), SA (South Asia), MENA, and SSA (Sub-Saharan Africa). In this paper OECD block does not include the Eastern European countries that have joined the Organization recently. Instead, these countries are accounted for in the EE region. A dummy equals to 1 if both country i \& country $\mathrm{j}$ belong to the same group and 0 otherwise.

$\varepsilon_{\mathrm{ijj}, \mathrm{t}}-$ residual.

\section{Identification issues}

As noted in the first section, study of growth and institutional development is subject to the endogeneity problem. Institutional quality is a factor of economic growth and simultaneously growth itself influences the quality of institutions. This is a well recognized problem in the empirical literature, though we run a formal test for endogeneity of the relative GDP variable. ${ }^{24}$ The null hypothesis of its exogeneity is rejected with $p$-value $=0.0000$ in all our specifications.

Recognizing this risk of endogeneity, relative GDP per capita is instrumented with variables borrowed from the classical economic growth studies (7).

\footnotetext{
${ }^{24}$ The endogeneity test is asymptotically distributed as Chi-squared with degrees of freedom equal to a number of potentially endogenous regressors and estimated as $\mathrm{C}$ statistics, i.e., as difference of $2 \mathrm{~J}$ statistics. One is for model that treats the variable(s) of interest as exogenous and includes it (them) in the list of IVs, while the other treats it (them) as endogenous.
} 
Relative $\mathrm{GDPC}_{\mathrm{ij, \textrm {t }}}=\delta_{0}+\delta_{1}$ Rel Investment $\mathrm{ij,t}_{\mathrm{t}}+\delta_{2}$ Rel Enrollment $_{\mathrm{ij,t}}+\varphi \mathrm{Z}_{\mathrm{j}, \mathrm{t}}+\omega_{\mathrm{ij, \textrm {t }}}$

where Rel Investment/GDP $\mathrm{ij}_{\mathrm{j}, \mathrm{t}}$ - absolute difference of Investment to GDP ratios between countries i \& j at year $\mathrm{t}$,

Rel Enrollment $\mathrm{ij}_{\mathrm{ij}, \mathrm{t}}$ - ratio of enrollment rates in secondary education institutions in countries $\mathrm{i} \& \mathrm{j}$ at year $\mathrm{t}$,

$\mathrm{Z}_{\mathrm{ij}, \mathrm{t}}-$ vector of other exogenous variables (both time varying and time invariant), $\eta_{\mathrm{ij}, \mathrm{t}}-$ residual.

Ratio of enrollment into secondary educational programs and difference in investment to GDP ratios are designed to represent, respectively, the role of human capital and investment for development. There are several reasons for choice of these variables as instruments: data availability and relevance of the instruments. First, these data are available for the large number of countries over the long periods of time .Second, the first stage estimation results suggest appropriate selection of these instrumental variables, which is reflected in the highly significant coefficient estimates. Therefore, our second stage estimation results are not subject to the weak instruments problem.

\section{Setup of the General Method of Moments Model}

Estimation of this overidentified model is conducted under GMM framework.

All models (3-7) can be compactly written as

$\vec{y}_{i j, t}=\vec{z}_{i j, t}^{\prime} \vec{\pi}+\vec{\varepsilon}_{i j, t}$

where $\vec{y}_{i j, t}=\left(\text { InstD ist }_{i j, t}\right)^{\prime}$ is a vector of dependent variables, either 4-component (WGI4) or 6component institutional index (WGI6) for all country pairs,

$\vec{z}_{i j, t}=\left(1\right.$, Relative GDPc $_{i j, t}$, Dist $_{i j}$, PopDens $_{i j, t}$, TradeOpen $_{i j, t}, \operatorname{RawX}_{i j, t}$,

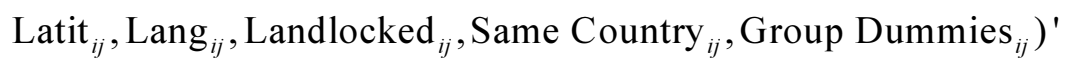

is a vector of explanatory (RHS) variables. Note that it includes presumably endogenous Relative GDP per capita variable, but does not include its instruments (Investment in physical capital and Human capital), 
$\vec{x}_{i j, t}=\left(1\right.$, Dist $_{i j}$, Pop Dens $_{i j, t}$, Trade Open $_{i j, t}, \operatorname{RawX}_{i j, t}$,

Latit $_{i j}$, Lang $_{i j}$, Landlocked $i j$, Same Country ${ }_{i j}$, Group Dummies ${ }_{i j}$, Investment $/ \mathrm{GDP}_{i j, t}$, Enrollment $\left._{i j, t}\right)^{\prime}$

is a vector of exogenous variables. Note that Relative GDP is not included, while its instruments - are,

$\vec{\pi}_{i j, t}$ is a vector of 11 estimated parameters,

$\vec{\varepsilon}_{i j, t}$ are residuals from the model (3-7) estimation.

Depending on the estimated model, some of the variables are excluded from the vectors of explanatory and predetermined variables. For example, $\mathrm{R} \mathrm{aw}_{i j, t}$ is omitted from (3) and (5), as

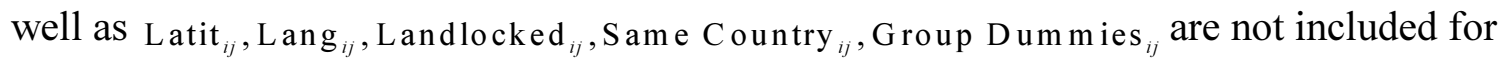
specifications (3) \& (4).

Using the above notations orthogonality or moment conditions can be written as $E\left[\vec{x}_{i j, t} \vec{\varepsilon}_{i j, t}\right]=0$. The model is linear in parameters.

As noted above, the results of the first stage estimation were analyzed to choose the set of exogenous variables. If the coefficient estimates for the selected instrumental variables were insignificant at the first stage that would result in the weak instruments problem at the second stage.

To summarize, the number of estimated parameters is determined by length of vector $\vec{z}, \mathrm{~L}=11$, and the number of predetermined variables corresponds to length of the vector $\vec{x}, \mathrm{~K}=12$. Therefore, the model is overidentified, rank condition is satisfied, i.e., Number of orthogonality conditions is greater than number of estimated parameters.

\section{Choice of Weights Matrix and GMM Estimator}

It is natural to assume heteroskedastic disturbances for this model: large dataset (22 $000-33000$ country-pair observations, depending on the model specification) includes country pairs that substantially differ in many regards, such as economy size, income per capita, human capital, structure of economy. This assumption is supported by the results of the Pagan-Hall test for heteroskedasticity for all specifications estimated in this paper. Null hypothesis of 
homoskedasticity is rejected with p-value 0.0000 for all specifications. Therefore, we choose to control for clustering of observations by country pairs and use heteroskedasticity consistent, HC, estimator (White standard errors).

Technically, we could use the weights matrix that controls for heteroskedasticity of unknown form (but not controlling for clusters) and consistent against autocorrelation, HAC (Newey-West standard errors). Yet, the available panel is quite limited in terms of time ( 8 years with average number of year observations per country equal to 4.5), while it includes more than 7000 clusters. Therefore, we prefer to control for clustering rather than autocorrelation.

Continuously Updated GMM Estimator, CUE, behaves preferably in small samples and is robust to weak instruments. However, to check robustness to the choice of estimator we estimate the model also with a 2 Step Efficient GMM. As it is shown below the coefficient estimates and corresponding confidence intervals produced by both estimators are very close. This result suggests robustness of the model to alternative estimators and relevance of the chosen instruments.

\section{Estimation Results}

This section starts with the presentation of estimation results for the basic model (3) and (4).Then it continues with their extension to include geographical and historical/cultural characteristics in specifications (5) and (6).

We would like to emphasize that the following features are common for all specification estimates:

- The estimation results obtained with alternative estimators, 2 Step Efficient GMM Estimator and Continuously Updated GMM Estimator, are almost identical.

- The endogeneity test suggests that relative GDP per capita is endogenous with $p$-value equal to 0.0000 .

- The underidentification test rejects the null hypothesis of underidentification with p-value of 0.0000 . 


\section{Basic Specification of the Modified Gravity Model}

The estimation results for the specification (3) are presented in Table 1. First, note that the high value of Hansen $J$ statistics suggests misspecification of the model at $1 \%$ significance level when WGI 6 is used as a dependent variable. If the 4-component institutional index is used, null hypothesis (of correct specification) for $\mathrm{J}$ statistic is not rejected (p-value 0.3088 ).

Coefficient of the relative GDP per capita is estimated positively, i.e., greater differences in income are associated with greater institutional differences. Also, the 4-component institutional index is more sensitive to differences in income. The coefficient for relative GDP per capita when WGI4 is used is 0.178 vs 0.144 when WGI6 is used as a LHS variable.

Geographical distances play similar role for differences in the institutional environment as a relative income. However, the estimated coefficient is about twice as small (0.082 for WGI4 and 0.089 for WGI 6) than for relative GDP per capita and in this case institutional distances measured with a 6-component index are more sensitive to this factor.

The coefficient for population density product is negative. It may have the following interpretation: All other factors being equal, the pair of countries with higher density of population has smaller institutional difference between each other. Higher population density may facilitate institutional development (institutional imports from the neighbors) in a way similar to how it helps to develop bilateral trade. Though statistically this effect is quite modest (-0.014 for WGI4 and -0.010 for WGI6).

Finally, the estimated effect of differences in trade openness on institutional distance is positive ( 0.06 for WGI4 and 0.048 for WGI6). Thus, the hypothesis of greater institutional similarities in countries with similar intensities of trade flows is not rejected.

Table 1. Basic specification of the model

\begin{tabular}{lllll} 
Dependent variable & WGI4 2S & WGI6 2S & WGI4 CUE & WGI6 CUE \\
\hline Relative GDP per capita & $0.178^{* * *}$ & $0.144^{* * *}$ & $0.178^{* * *}$ & $0.144^{* * *}$ \\
& $(27.91)$ & $(26.35)$ & $(27.91)$ & $(26.37)$
\end{tabular}




\begin{tabular}{lllll} 
Geographical Distances & $0.082^{* * *}$ & $0.089^{* * *}$ & $0.082^{* * *}$ & $0.089^{* * *}$ \\
& $(7.29)$ & $(8.85)$ & $(7.29)$ & $(8.83)$ \\
Population Density & $-0.014 * *$ & $-0.010^{* *}$ & $-0.014^{* *}$ & $-0.010^{* *}$ \\
& $(-3.15)$ & $(-2.58)$ & $(-3.15)$ & $(-2.58)$ \\
Trade Openness & $0.060^{* * *}$ & $0.048^{* * *}$ & $0.060^{* * *}$ & $0.048^{* * *}$ \\
& $(9.11)$ & $(8.53)$ & $(9.11)$ & $(8.53)$ \\
Intercept & $-0.293 * *$ & -0.034 & $-0.293^{* *}$ & -0.033 \\
& $(-2.69)$ & $(-0.36)$ & $(-2.69)$ & $(-0.35)$ \\
\hline R-sq uncentered & 0.523 & 0.729 & 0.523 & 0.729 \\
R-sq centered & 0.195 & 0.185 & 0.195 & 0.185 \\
N of observations & 32503 & 32503 & 32503 & 32503 \\
N of clusters & 7705 & 7705 & 7705 & 7705 \\
F statistics & 258.180 & 237.476 & 258.230 & 237.618 \\
J statistic & 1.036 & 10.400 & 1.036 & 10.397 \\
J statistic p-value & 0.3088 & 0.0013 & 0.3088 & 0.0013 \\
J statistic degrees of freedom & 1 & 1 & 1 & 1 \\
LM underidentification test & 1820.850 & 1820.850 & 1820.850 & 1820.850 \\
LM test p-value & 0.0000 & 0.0000 & 0.0000 & 0.0000 \\
LM test degrees of freedom & 2 & 2 & 2 & 2 \\
Endogeneity of relative GDP test & 47.085 & 35.586 & 47.085 & 35.586 \\
Endogeneity of relative GDP test p-value & 0.0000 & 0.0000 & 0.0000 & 0.0000
\end{tabular}

Notes: GMM estimation. HC clustered standard errors reported in parentheses. All variables are in logs. Stars denote significance level: ${ }^{*}$ - p- value $<0.1, * *-$ p- value $<0.05, * * *-$ p-value $<0.01$.

WGI4 -depended variable is the 4-component institutional index; WGI6 -the 6-component institutional index; 2S - 2 Step Efficient GMM Estimator; CUE - Continuously Updated GMM Estimator.

Table 2 contains the estimation results for specification (4). Similarly to specification (3), for specification (4) with 4-component institutional distances $\mathrm{J}$ test does not reject null hypothesis of correct specification of the model, while the option with WGI6 as a dependent variable does not pass this test. The results mainly repeat those in Table 1, except that the population density becomes insignificant. The added variable, absolute difference in shares of raw materials exports, is estimated always positively and almost twice larger (0.039 vs. 0.021$)$ for WGI6 than for WGI4.The coefficient for trade openness slightly diminishes (to 0.052 from 0.06 for WGI4).

The results in Table 2 suggest that the natural resource component of exports is a significant explanatory factor of institutional differences. Nations with a high share of natural resource 
exports show greater institutional differences from their peers, i.e. they exhibit institutional backwardness, and their political institutions are affected to a greater extent than the economic ones.

In other words, the latter estimates suggest that institutional differences grow as the crosscountry differences in the export share of raw materials expand. The "resource curse" concept suggests an explanation of this result. The Resource curse affects institutional development through different channels (Moore, 1998; Tornell and Lane, 1999). First, in the natural resource abundant countries there is insufficiency of incentives to reform their institutional framework, since political elites enjoy major benefits from the exploitation of the national natural resource sector under the existing, but sub-optimal, institutional framework. The consequence is weak governance and poor institutional climate, and this undermines incentives for investment in the country, unless an investor develops special relationships with the governing elites. Second, problems in investment climate are aggravated by Dutch Disease (appreciation of the national currency, decline of the tradables sector, lower incomes in the non-resource extractive sector).

Table 2. Basic specification and resource curse

\begin{tabular}{lllll} 
Dependent variable & WGI4 2S & WGI6 2S & WGI4 CUE & WGI6 CUE \\
\hline Relative GDP per capita & $0.184^{* * *}$ & $0.149^{* * *}$ & $0.184^{* * *}$ & $0.149^{* * *}$ \\
& $(26.65)$ & $(25.36)$ & $(26.66)$ & $(25.38)$ \\
Geographical Distances & $0.068^{* * *}$ & $0.076^{* * *}$ & $0.068^{* * *}$ & $0.076^{* * *}$ \\
& $(5.66)$ & $(7.09)$ & $(5.66)$ & $(7.08)$ \\
Population Density & -0.007 & 0.001 & -0.007 & 0.001 \\
& $(-1.28)$ & $(0.28)$ & $(-1.28)$ & $(0.28)$ \\
Trade Openness & $0.052^{* * *}$ & $0.043 * * *$ & $0.052^{* * *}$ & $0.043^{* * *}$ \\
& $(7.22)$ & $(6.90)$ & $(7.22)$ & $(6.91)$ \\
Raw Materials Exports & $0.021^{* * *}$ & $0.039^{* * *}$ & $0.021^{* * *}$ & $0.039 * * *$ \\
& $(3.46)$ & $(7.54)$ & $(3.46)$ & $(7.54)$ \\
Intercept & $-0.285^{*}$ & -0.126 & $-0.285^{*}$ & -0.125 \\
& $(-2.37)$ & $(-1.18)$ & $(-2.37)$ & $(-1.18)$ \\
\hline R-sq uncentered & 0.511 & 0.719 & 0.511 & 0.719 \\
R-sq centered & 0.197 & 0.191 & 0.197 & 0.191 \\
N of observations & 26733 & 26733 & 26733 & 26733 \\
N of clusters & 6697 & 6697 & 6697 & 6697
\end{tabular}




$\begin{array}{lllll}\text { F statistics } & 175.564 & 168.685 & 175.587 & 168.733 \\ \text { J statistic } & 0.200 & 5.328 & 0.200 & 5.327 \\ \text { J statistic p-value } & 0.6544 & 0.0210 & 0.6544 & 0.0210 \\ \text { J statistic degrees of freedom } & 1 & 1 & 1 & 1 \\ \text { LM underidentification test } & 1576.293 & 1576.293 & 1576.293 & 1576.293 \\ \text { LM test p-value } & 0.0000 & 0.0000 & 0.0000 & 0.0000 \\ \text { LM test degrees of freedom } & 2 & 2 & 2 & 2 \\ \text { Endogeneity of relative GDP test } & 61.860 & 50.026 & 61.860 & 50.026 \\ \text { Endogeneity of relative GDP test p-value } & 0.0000 & 0.0000 & 0.0000 & 0.0000\end{array}$

Notes: GMM estimation. HC clustered standard errors reported in parentheses. All variables in logs. Stars denote significance level: ${ }^{*}$ - p- value $<0.1, * *-$ p- value $<0.05, * * *-$ p-value $<0.01$. WGI4 - regressand is the 4 component institutional index; WGI6 - regressand is the 6 component institutional index; 2S - 2 Step Efficient GMM Estimator; CUE - Continuously Updated GMM Estimator.

\section{Extended Specification of the Modified Gravity Model}

Table 3 and Table 4 present estimations of 2 additional specifications ( 5 and 6 ) of our modified gravity model. Additional specifications are based on the earlier specifications (3 and 4), respectively, and extended to include extra explanatory variables that control for geographical and historical differences across the countries. We would like to emphasize that both specifications 5 and 6 pass Hansen J statistic test for overidentification.

Table 3 represents the results for the extended model. One of the main findings is that once the new explanatory variables were added, the estimate for the geographical distances coefficient decreased in absolute value and changed its sign (to -0.077 for WGI4 and -0.058 for WGI6). This suggests that geography is an important factor of institutional development, but not per se. It operates through other variables, included in the extended specification, such as trade-related geographical and cultural characteristics. Thus, the initially observed in the basic model effect of geographical distance on institutional differences disappears, as the new variables are added. Yet, the extended specification with regional dummies is preferred to the basic model, since it gives more detailed information on the drivers of institutional differences than just a single geographical distances variable. 
Relative GDP per capita and population density coefficients maintain their respective signs and so does the interpretation of these estimates. The value of the relative GDP coefficient moderately decreases for both 4 - and 6-component institutional distances $(0.171 / 0.134$ vs. $0.178 / 0.144$ in specification (3)).

Population density is significant for both WGI4 and WGI6 with respective coefficient values of $0.016 /-0.011$.

Absolute difference of latitudes is estimated positively $(0.012 / 0.011)$, which point to the fact that countries located at an approximately same distance from equator have on average similar institutional characteristics.

The coefficient for landlocked dummy is positive (0.091/0.085), which reflects importance of direct access to sea routes for institutional development. Note that this variable takes value of 1 if only one of the countries in the given country pair is landlocked and 2 if both are. Thus model predicts that if both countries in any pair are landlocked, this considerably affects their institutional convergence -- they will have on average 17-18\% greater institutional distance from each other than in the pair where two countries have sea access. This result supports the hypothesis that trade facilitates institutional changes.

The effect of common language is estimated negatively at $1 \%$ confidence level with the coefficient of $-0.103 /-0.074$, i.e. greater absolute value for WGI4 specification, i.e. common language, as expected, supports institutional similarities (smaller institutional distances), i.e. convergence.

Being parts of the same country in the past suggests exposure to the common history, culture, and language. Some or all of these characteristics vary with the length of being within a single state and length of time that passed after gaining independence (break-up), therefore, this is another factor, which potentially can explain differences in the institutional environment. This coefficient is estimated negatively, with the p-value equal to $0.073 / 0.053$.

The set of geographical dummies that indicates whether the countries are members of the same political or economical unions or are located in the same geographical region further improves the model. We observe that indeed national institutional characteristics are closer between the 
countries that jointly belong to such unions (with exception on Eastern Asian countries, which apparently exhibit extreme heterogeneity within their own group).

As was noted above, $\mathrm{J}$ statistic is low for specifications with both dependent variables, therefore, hypothesis of correct model identification is not rejected.

Table 3. Extended specification of the modified gravity model

\begin{tabular}{|c|c|c|c|c|}
\hline Dependent variable & WGI4 2S & WGI6 2S & WGI4 CUE & WGI6 CUE \\
\hline \multirow[t]{2}{*}{ Relative GDP per capita } & $0.171 * * *$ & $0.134 * * *$ & $0.171 * * *$ & $0.134 * * *$ \\
\hline & $(30.84)$ & $(29.49)$ & $(30.84)$ & $(29.50)$ \\
\hline \multirow[t]{2}{*}{ Geographical Distances } & $-0.077 * * *$ & $-0.058 * * *$ & $-0.077 * * *$ & $-0.058 * * *$ \\
\hline & $(-6.47)$ & $(-5.71)$ & $(-6.47)$ & $(-5.71)$ \\
\hline \multirow[t]{2}{*}{ Population Density } & $-0.016 * * *$ & $-0.011 * *$ & $-0.016 * * *$ & $-0.011 * *$ \\
\hline & $(-3.87)$ & $(-3.14)$ & $(-3.87)$ & $(-3.14)$ \\
\hline \multirow[t]{2}{*}{ Trade Openness } & $0.045 * * *$ & $0.034 * * *$ & $0.045 * * *$ & $0.034 * * *$ \\
\hline & $(7.43)$ & $(6.70)$ & $(7.43)$ & $(6.70)$ \\
\hline \multirow[t]{2}{*}{ Absolute Difference of Latitudes } & $0.012 * * *$ & $0.011 * * *$ & $0.012 * * *$ & $0.011 * * *$ \\
\hline & $(22.36)$ & $(23.43)$ & $(22.37)$ & $(23.43)$ \\
\hline \multirow[t]{2}{*}{ Common Language } & $-0.103 * * *$ & $-0.074 * * *$ & $-0.103 * * *$ & $-0.074 * * *$ \\
\hline & $(-5.51)$ & $(-4.94)$ & $(-5.51)$ & $(-4.94)$ \\
\hline \multirow[t]{2}{*}{ Landlocked } & $0.091 * * *$ & $0.085 * * *$ & $0.091 * * *$ & $0.085 * * *$ \\
\hline & $(6.25)$ & $(6.83)$ & $(6.25)$ & $(6.84)$ \\
\hline \multirow[t]{2}{*}{ Same Country in the past } & $-0.122 *$ & $-0.116^{*}$ & $-0.122 *$ & $-0.116^{*}$ \\
\hline & $(-1.79)$ & $(-1.94)$ & $(-1.79)$ & $(-1.94)$ \\
\hline \multirow[t]{2}{*}{ OECD } & $-0.549 * * *$ & $-0.643 * * *$ & $-0.549 * * *$ & $-0.643 * * *$ \\
\hline & $(-11.79)$ & $(-15.78)$ & $(-11.79)$ & $(-15.78)$ \\
\hline \multirow[t]{2}{*}{ EE } & $-0.647 * * *$ & $-0.753 * * *$ & $-0.647 * * *$ & $-0.753 * * *$ \\
\hline & $(-7.52)$ & $(-8.69)$ & $(-7.52)$ & $(-8.68)$ \\
\hline \multirow[t]{2}{*}{ CIS } & $-0.895 * * *$ & $-0.665 * * *$ & $-0.895 * * *$ & $-0.665^{* * *}$ \\
\hline & $(-10.83)$ & $(-11.85)$ & $(-10.83)$ & $(-11.85)$ \\
\hline \multirow[t]{2}{*}{ LAC } & $-0.278 * * *$ & $-0.287 * * *$ & $-0.278 * * *$ & $-0.287 * * *$ \\
\hline & $(-5.18)$ & $(-6.25)$ & $(-5.18)$ & $(-6.25)$ \\
\hline \multirow[t]{2}{*}{ EA } & -0.169 & -0.104 & -0.169 & -0.104 \\
\hline & $(-1.56)$ & $(-1.38)$ & $(-1.56)$ & $(-1.38)$ \\
\hline \multirow[t]{2}{*}{ SA } & $-0.336^{*}$ & $-0.333 * *$ & $-0.336^{*}$ & $-0.333 * *$ \\
\hline & $(-1.79)$ & $(-2.25)$ & $(-1.79)$ & $(-2.25)$ \\
\hline \multirow[t]{2}{*}{ MENA } & $-0.151 * *$ & $-0.166^{* * *}$ & $-0.151 * *$ & $-0.166^{* * *}$ \\
\hline & $(-2.75)$ & $(-3.41)$ & $(-2.75)$ & $(-3.42)$ \\
\hline \multirow[t]{2}{*}{ SSA } & $-0.428 * * *$ & $-0.324 * * *$ & $-0.428 * * *$ & $-0.324 * * *$ \\
\hline & $(-10.65)$ & $(-9.61)$ & $(-10.65)$ & $(-9.61)$ \\
\hline
\end{tabular}




\begin{tabular}{lllll} 
Intercept & $\begin{array}{lll}1.963^{* * *} \\
(8.39)\end{array}$ & $\begin{array}{l}1.128^{* * *} \\
(11.70)\end{array}$ & $\begin{array}{l}0.963^{* * *} \\
(8.39)\end{array}$ & $\begin{array}{l}1.128^{* * *} \\
(11.70)\end{array}$ \\
\hline R-sq uncentered & 0.593 & 0.778 & 0.593 & 0.778 \\
R-sq centered & 0.314 & 0.333 & 0.314 & 0.333 \\
N of observations & 32503 & 32503 & 32503 & 32503 \\
N of clusters & 7705 & 7705 & 7705 & 7705 \\
F statistics & 225.387 & 234.268 & 225.392 & 234.236 \\
J statistic & 0.095 & 1.530 & 0.095 & 1.530 \\
J statistic p-value & 0.7585 & 0.2161 & 0.7585 & 0.2162 \\
J statistic degrees of freedom & 1 & 1 & 1 & 1 \\
LM underidentification test & 1728.769 & 1728.769 & 1728.769 & 1728.769 \\
LM test p-value & 0.0000 & 0.0000 & 0.0000 & 0.0000 \\
LM test degrees of freedom & 2 & 2 & 2 & 2 \\
Endogeneity of relative GDP test & 20.989 & 12.858 & 20.989 & 12.858 \\
Endogeneity of relative GDP test p-value & 0.0000 & 0.0003 & 0.0000 & 0.0003
\end{tabular}

Notes: GMM estimation. HC clustered standard errors reported in parentheses. All variables in logs. Stars denote significance level: ${ }^{*}$ - p- value $<0.1, *^{*}$ - p- value $<0.05, *^{* *}-$ p-value $<0.01$. WGI 4 - regressand is the 4 component institutional index; WGI6 - regressand is the 6 component institutional index; $2 \mathrm{~S}-2$ Step Efficient GMM Estimator; CUE - Continuously Updated GMM Estimator.

Specification (6) extends model (5), in a way similar to how the specification (4) extended specification (3), i.e. by adding the share of raw materials exports variable to test the resource curse hypothesis for the extended model. Results are very similar to the specification (5). Note that if WGI4 is used as an explained variable, raw materials export is estimated with p-value equal to 0.074 . For WGI6 the specification coefficient estimate is significant at the $1 \%$ confidence level. Once again, we interpret these results as evidence of resource curse that hinders institutional development and institutional convergence.

The coefficient of the same country dummy is still estimated negatively, however, the p-value has increased to $0.11 / 0.103$. Probably, after we control in the model for language, being landlocked, latitude differences, and raw materials exports, the amount of new information contained in the same country dummy is relatively limited. 
Table 4. Extended specification and resource curse

\begin{tabular}{|c|c|c|c|c|}
\hline Dependent variable & WGI4 2S & WGI6 2S & WGI4 CUE & WGI6 CUE \\
\hline \multirow[t]{2}{*}{ Relative GDP per capita } & $0.175 * * *$ & $0.137 * * *$ & $0.175 * * *$ & $0.137 * * *$ \\
\hline & $(28.51)$ & $(27.41)$ & $(28.50)$ & $(27.41)$ \\
\hline \multirow[t]{2}{*}{ Geographical Distances } & $-0.083 * * *$ & $-0.065 * * *$ & $-0.083 * * *$ & $-0.065 * * *$ \\
\hline & $(-6.59)$ & $(-6.06)$ & $(-6.59)$ & $(-6.06)$ \\
\hline \multirow[t]{2}{*}{ Population Density } & $-0.013 * *$ & -0.005 & $-0.013 * *$ & -0.005 \\
\hline & $(-2.62)$ & $(-1.24)$ & $(-2.62)$ & $(-1.24)$ \\
\hline \multirow[t]{2}{*}{ Trade Openness } & $0.037 * * *$ & $0.028 * * *$ & $0.037 * * *$ & $0.028 * * *$ \\
\hline & $(5.40)$ & $(4.93)$ & $(5.40)$ & $(4.93)$ \\
\hline \multirow[t]{2}{*}{ Raw Materials Exports } & $0.010^{*}$ & $0.025 * * *$ & $0.010^{*}$ & $0.025 * * *$ \\
\hline & $(1.79)$ & $(5.21)$ & $(1.79)$ & $(5.21)$ \\
\hline \multirow[t]{2}{*}{ Absolute Difference of Latitudes } & $0.011 * * *$ & $0.010 * * *$ & $0.011 * * *$ & $0.010 * * *$ \\
\hline & $(18.70)$ & $(20.06)$ & $(18.70)$ & $(20.06)$ \\
\hline \multirow[t]{2}{*}{ Common Language } & $-0.094 * * *$ & $-0.066 * * *$ & $-0.094 * * *$ & $-0.066 * * *$ \\
\hline & $(-4.60)$ & $(-3.98)$ & $(-4.60)$ & $(-3.98)$ \\
\hline \multirow[t]{2}{*}{ Landlocked } & $0.075 * * *$ & $0.062 * * *$ & $0.075 * * *$ & $0.062 * * *$ \\
\hline & $(4.61)$ & $(4.48)$ & $(4.61)$ & $(4.48)$ \\
\hline \multirow[t]{2}{*}{ Same Country in the past } & -0.119 & -0.106 & -0.119 & -0.106 \\
\hline & $(-1.60)$ & $(-1.63)$ & $(-1.60)$ & $(-1.63)$ \\
\hline \multirow[t]{2}{*}{ OECD } & $-0.542 * * *$ & $-0.615 * * *$ & $-0.542 * * *$ & $-0.615 * * *$ \\
\hline & $(-11.49)$ & $(-14.87)$ & $(-11.49)$ & $(-14.87)$ \\
\hline \multirow[t]{2}{*}{$\mathrm{EE}$} & $-0.646 * * *$ & $-0.731 * * *$ & $-0.646 * * *$ & $-0.731 * * *$ \\
\hline & $(-7.44)$ & $(-8.37)$ & $(-7.45)$ & $(-8.37)$ \\
\hline \multirow[t]{2}{*}{ CIS } & $-0.981 * * *$ & $-0.730 * * *$ & $-0.981 * * *$ & $-0.730 * * *$ \\
\hline & $(-9.88)$ & $(-10.91)$ & $(-9.88)$ & $(-10.91)$ \\
\hline \multirow[t]{2}{*}{ LAC } & $-0.249 * * *$ & $-0.261 * * *$ & $-0.249 * * *$ & $-0.261 * * *$ \\
\hline & $(-4.27)$ & $(-5.26)$ & $(-4.27)$ & $(-5.26)$ \\
\hline \multirow[t]{2}{*}{ EA } & $-0.262 * *$ & $-0.151 *$ & $-0.262 * *$ & $-0.151 *$ \\
\hline & $(-2.18)$ & $(-1.86)$ & $(-2.18)$ & $(-1.86)$ \\
\hline \multirow[t]{2}{*}{ SA } & -0.315 & $-0.339 *$ & -0.315 & $-0.339 *$ \\
\hline & $(-1.51)$ & $(-2.16)$ & $(-1.51)$ & $(-2.16)$ \\
\hline \multirow[t]{2}{*}{ MENA } & $-0.210 * * *$ & $-0.201 * * *$ & $-0.210 * * *$ & $-0.201 * * *$ \\
\hline & $(-3.43)$ & $(-3.64)$ & $(-3.43)$ & $(-3.64)$ \\
\hline \multirow[t]{2}{*}{ SSA } & $-0.455 * * *$ & $-0.347 * * *$ & $-0.455 * * *$ & $-0.347 * * *$ \\
\hline & $(-9.70)$ & $(-8.92)$ & $(-9.70)$ & $(-8.92)$ \\
\hline \multirow[t]{2}{*}{ Intercept } & $0.996 * * *$ & $1.104 * * *$ & $0.996 * * *$ & $1.104 * * *$ \\
\hline & $(8.03)$ & $(10.51)$ & $(8.03)$ & $(10.51)$ \\
\hline R-sq uncentered & 0.578 & 0.766 & 0.578 & 0.766 \\
\hline R-sq centered & 0.307 & 0.328 & 0.307 & 0.328 \\
\hline $\mathrm{N}$ of observations & 26733 & 26733 & 26733 & 26733 \\
\hline
\end{tabular}




$\begin{array}{lllll}\text { N of clusters } & 6697 & 6697 & 6697 & 6697 \\ \text { F statistics } & 163.623 & 174.271 & 163.633 & 174.252 \\ \text { J statistic } & 0.535 & 0.465 & 0.535 & 0.465 \\ \text { J statistic p-value } & 0.4644 & 0.4955 & 0.4644 & 0.4955 \\ \text { J statistic degrees of freedom } & 1 & 1 & 1 & 1 \\ \text { LM underidentification test } & 1496.262 & 1496.262 & 1496.262 & 1496.262 \\ \text { LM test p-value } & 0.0000 & 0.0000 & 0.0000 & 0.0000 \\ \text { LM test degrees of freedom } & 2 & 2 & 2 & 2 \\ \text { Endogeneity of relative GDP test } & 34.777 & 25.847 & 34.777 & 25.847 \\ \text { Endogeneity of relative GDP test p-value } & 0.0000 & 0.0000 & 0.0000 & 0.0000\end{array}$

Notes: GMM estimation. HC clustered standard errors reported in parentheses. All variables in logs. Stars denote significance level: ${ }^{*}$ - p- value $<0.1, * *$ - p- value $<0.05, *^{* *}$ - p-value $<0.01$.

WGI 4 - regressand is the 4 component institutional index; WGI6 - regressand is the 6 component institutional index; 2S - 2 Step Efficient GMM Estimator; CUE - Continuously Updated GMM Estimator.

\section{Conclusions}

Using the modified gravity model of trade, we studied institutional differences among more than 100 countries of the world over the period of 1996 - 2006. Our main findings and conclusions could be summarized as follows:

- Geographical and historical factors are significant determinants of cross-country differences in the institutional quality. Factors that are commonly considered to be drivers of bilateral commodity trade (distance, common language, being landlocked, membership in the same regional group) facilitate similarities in the levels of institutional development, i.e. institutional convergence. These results are received when we control for cross-country differences in per capita incomes.

- The obtained results suggest that institutional progress has some specific geographic patterns. Institutional progress in a given country depends on its physical (territorial) neighborhood. Countries tend to cluster by the level of their institutional development. Import of institutions is stimulated by demonstration effects from the nearby states. 
- Institutional development is facilitated by participation in international trade, and could take the form of import of new institutions from major trade partners. This is because participation in the international trade strengths the demand for more advanced institutions, stimulates adopting institutions from more developed partners. Countries with a similar level of trade openness, ceteris paribus, tend to demonstrate smaller institutional differences.

- Institutional similarities and differences are to a large extent determined by the commodity structure of trade flows. Dominance of trade in raw materials, as measured by absolute differences in shares of raw materials exports, (all other factors being equal) influences institutional progress negatively, it tends to increase institutional distances, especially if political institutions are included in the analysis.

- The model is robust to different measures of institutional distances used as dependent variables and therefore helps to explain both differences in economic institutions and in political and economic institutions combined. 


\section{References}

Acemoglu, Daron, Simon Johnson, James Robinson (2001) The Colonial Origins of Comparative Development: An Empirical Investigation, American Economic Review, Vol. 91: 1369-1401.

Anderson, James E. (1979) A Theoretical Foundation for the Gravity Equation, The American Economic Review, Vol. 69, No. 1 (Mar., 1979), pp. 106-116.

Barro, Robert J. (1996) Determinants of Economic Growth: A Cross-Country Empirical Study, NBER Working Paper No. 5698.

Beck, Thorsten, Asli Demirguc-Kunt, Ross Levine, Vojislav Maksimovic (2001) Financial Structure and Economic Development: Firm, Industry, and Country Evidence in Financial Structure and Economic Growth. Cambridge, MA: MIT Press, 2001.

Braudel, Fernand (1972) The Mediterranean and the Mediterranean World in the Age of Philip II. New York: Harper \& Row.

Braudel, Fernand (1981-1984) Civilization and Capitalism, 15th-18th Century. London: Collins. 3 volumes.

Clague, Christopher. (ed.) (1997). Institutions and Economic Development: Growth and Governance in Less-Developed and Post-Socialist Countries. Baltimore and London: John Hopkins University Press.

Diamond, Jared (1997) Guns, Germs, and Steel: The Fates of Human Societies. New York: WW Norton.

Easterly, William, Ross Levine (2003) Tropics, germs, and crops: the role of endowments in economic development, Journal of Monetary Economics, 50:1.

Easterly, William, Jozef Ritzan, Michael Woolcock (2006) Social Cohesion, Institutions, and Growth, Working Papers 94, Center for Global Development.

Frankel, Jeffrey (1997) Regional Trading Blocs in the World Economic System, Washington DC: Institute for International Economics.

Frankel, Jeffrey, Andrew Rose (2005) Is Trade Good or Bad for the Environment? Sorting out the Causality. The Review of Economics and Statistics, February 2005, 87(1): 85-91.

Gallup, John, Jeffrey Sachs, Andrew Mellinger (1999) Geography and Economic Development, International Regional Science Review, Vol. 22: 179-232.

Hahm, Joon-Ho, Kwanho Shin (2009) Complementarity among International Asset Holdings. Journal of Japanese and International Economies, 23:1, pp. 37-55. 
Hausmann, Ricardo, Lant Pritchett, Dani Rodrik, Growth Accelerations, Journal of Economic Growth, 10(4), December 2005, 303 - 329.

Helpman, Elhanan, Paul Krugman (1985) Market Structure and Foreign Trade, MIT Press.

Kaufmann, Daniel, Aart Kraay, Massimo Mastruzzi (2007) Governance Matters VI: Governance Indicators for 1996-2006. World Bank Policy Research Working Paper 4280.

Kaufmann, Daniel, Aart Kraay, Pablo Zoido-Lobatón (1999a) Aggregating Governance Indicators. World Bank Research Working Paper 2195.

Kaufmann, Daniel, Aart Kraay, Pablo Zoido-Lobatón (1999b) Governance Matters. World Bank Research Working Paper 2196.

Keefer, Philip, Stephen Knack (1997) Why Don't Poor Countries Catch Up? A Cross-National Test of Institutional Explanation, Economic Inquiry 35: 590-602.

King, Robert G., Ross Levine (1993a) Finance, Entrepreneurship, and Growth: Theory and Evidence. Journal of Monetary Economics, December, 32(3), 513-542.

King, Robert G., Ross Levine (1993b) Finance and Growth: Schumpeter Might Be Right. Quarterly Journal of Economics, Vol. 153, August, 717-738.

La Porta, Rafael, Florencio Lopez-de-Silanes, Cristian Pop-Eleches, Andrei Shleifer (2004) Judicial Checks and Balances, Journal of Political Economy, vol. 112(2), 445-470.

Martin, Philippe, Helene Rey (2004) Financial Supermarkets: Size Matters for Asset Trade, Journal of International Economics. 64 (2), pp. 335-361, December.

Mauro, Paulo (1995) Corruption and Growth, The Quarterly Journal of Economics, Vol. 110.

Mayer, Thierry, Soledad Zignago (2006) Notes on CEPII's distances measures, http://www.cepii.fr/anglaisgraph/bdd/distances.htm.

Moore, Mick (1998) Death without Taxes: Democracy, State Capacity, and Aid Dependence in the Fourth World. In: Robinson, Mark, White, Gordon (Eds.), The Democratic Developmental State: Political and Institutional Design. Oxford Univ. Press, Oxford.

North, Douglas, Robert P. Thomas (1973) The Rise of the Western World: A New Economic History, Cambridge: Cambridge University Press.

Olson, Mancur (2000) Power and Prosperity: Outgrowing Communist and Capitalist Dictatorships, Basic Books.

Portes, Richard, Helene Rey (2005) The Determinants of Cross-border Equity Flows. Journal of International Economics. 65, pp. 269-296.

Putnam, Robert, John Helliwell (1995) Economic growth and social capital in Italy, Eastern Economic Journal, Summer. 
Redding, Stephen, Anthony Venables (2000) Economic Geography and International Inequality: Discussion Paper 2568, Center for Economic Policy Research.

Rodrik, Dani (2003) In Search of Prosperity: Analytical Narratives on Economic Growth. Princeton University Press.

Rodrik, Dani, Arvind Subramanian, Francesco Trebbi (2002) Institutions Rule: The Primacy of Institutions over Geography and Integration in Economic Development, NBER Working Paper No. 9305.

Sachs, Jeffrey (2003) Institutions Don't Rule: Direct Effects of Geography on Per Capita Income, NBER Working Paper No. W9490.

Sachs, Jeffrey, Andrew Warner (1995) Economic Reform and the Process of Global Integration, Brookings Papers on Economic Activity, 1: 1-95.

Shleifer, Andrei, Rafael La Porta, Florencio Lopez-de-Silanes, Robert Vishny (1997) Legal Determinants of External Finance, Journal of Finance.

Shleifer, Andrei, Rafael La Porta, Florencio Lopez-de-Silanes, Robert Vishny (1998) Law and Finance, Journal of Political Economy.

Shleifer, Andrei, Edward Glaeser, Rafael La Porta, Florencio Lopez-de-Silanes (2004) Do Institutions Cause Growth? Journal of Economic Growth, 9:271-303.

Tornell, Aaron, and Philip R. Lane (1999) The Voracity Effect. American Economic Review, 89(1): 22-46.

Tinbergen, Jan (1962) Shaping the World Economy: Suggestions for an International Economic Policy, Twentieth Century Fund.

Wurgler, Jeffrey (2000) Financial Markets and the Allocation of Capital, Journal of Financial Economics, Vol. 58(1-2): 187-214. 